\title{
The Strategiof Madrasah Headmaster in Improving The Quality of Islamic Education
}

\author{
Sakinah Sakinah ${ }^{1 *}$,Asy'ari Asy'ari ${ }^{2}$, and Moh. $\mathrm{Ali}^{3}$ \\ ${ }^{1}$ Islamic Education Department, Postgraduate, Institut Agama Islam Negeri Palu \\ ${ }^{2}$ Islamic Education Department, Postgraduate, Institut Agama Islam Negeri Palu \\ ${ }^{3}$ Islamic Education Department, Postgraduate, Institut Agama Islam Negeri Palu
}

ABSTRACT

This study examines the strategies of madrasa headmasters in improving the quality of Islamic Education and the facilitating and hindering factors as well as the solutions of the headmaster's strategies in improving the quality of Islamic Education in Madrasah Tsanawiyah. This study used descriptive qualitative and research design using a case study approach. The data were collected using observation, interview and documentation techniques. Data analysis techniques through data reduction analysis, data presentation and data verification which ended with checking the validity of the data. The results showed that: 1) The strategy employed by the madrasah headmaster in improving the quality of Islamic Education begins with an analysis of the internal and external environment of the madrasa which includes strengths and weaknesses, as well as the threats and opportunities. Head of Madrasah TsanawiyahAlkhairaatSibalaya always builds harmony in the organization for example being able to place personnel appropriately and influence his subordinates in human relationships which are covered by authority situations, enforce discipline to all madrasa personnel, and empower teachers to improve their competency, and evaluate by involving relevant and professional related parties.2) The supporting factors are harmonious cooperation with subordinates as well as the conducive and comfortable situation and conditions of madrasa. Meanwhile, inhibiting factors are the lack of teachers discipline and lack of community response to send their children to madrasas.
ARTICLE INFORMATION

Keywords:

Strategy

Headmaster,

Quality Learning, madrasah, 


\section{Pendahuluan}

Madrasah is "isimmakān" from the word "darasa" in Arabic, which means a place to sit or learn or widely known as madrasah. This Islamic educational institution began to grow in Indonesia at the beginning of the 20th century. The birth of the madrasah was inseparable from dissatisfaction with the pesantren (islamic boarding school) system at that time which merely focused on the study of Islamic religion while the general education system disregarded religion. ${ }^{1}$

The educational procedures are arranged where there are teachers, students, lesson schedules based on the curriculum, syllabus, and lesson plan (there are certain hours for learning and are equipped with educational facilities, both hardware and software). ${ }^{2}$ Madrasah is a form of Islamic educational institution that has a very long history. Islamic education, in general, emerged and developed along with the emergence of Islam itself, which starts from education at home, especially in matters relating to aqidah (faith).

To implement Madrasah-Based Management effectively and efficiently, madrasah headmasters are required to have

\footnotetext{
${ }^{1}$ Hasbullah, Kapita Selekta Pendidikan Islam (Cet. I; Jakarta: RajaGrafindo Persada, 1996), 66.

${ }^{2}$ Jasa Ungguh Muliawan, Pendidikan Integratif: Upaya Mengintegrasikan Kembali Dikotomi Ilmu dan Pendidikan Islam (Cet. I; Yogyakarta: Pustaka Pelajar, 2005), 155.
}

knowledge of leadership, planning, and have a broad insight of madrasas and education. The authority of the madrasah headmasters must be developed by increasing their compassion, learning enthusiasm, discipline, and human relations as manifestation of a conducive working atmosphere. Furthermore, they are demanded to perform as the madrasah manager in improving the learning process by conducting classroom supervision, guiding, and giving positive suggestions to educators. In addition, they must also exchange ideas, contribute suggestions, and do comparative studies among madrasas to learn leadership skills from other headmasters. ${ }^{3}$

Madrasas as an Educational Institution deal with two demands, from the community and from the business world. The demands are about the issues of low quality of education and the relevance to the development of community needs in the industrialization and globalization era. ${ }^{4}$

The first demand regarding the quality of education is mandatory and becomes top priority. When an education has good quality, the problem of relevance to the

${ }^{3}$ E. Mulyasa,Konsep, Strategi, dan Implementasi (Cet. XIII; Bandung: Remaja Rosdakarya, 2002), 57.

${ }^{4}$ Mulyoto, dkk. Kepemimpinan Kepala Madrasah Dalam Meningkatkan Mutu Madrasah Studi Kasus Tentang Manajemen Kepala Madrasah Tsanawiyah Negeri Bendosari Sukoharjo, (JurnalTeknologiPendidikan, Vol 1, No 2, 2013), 199-213. 
development of community needs that occur in the current era of globalization and industrializationwill automatically be solved.

Quality national education is directed to develop the potential of students to be faithful human beings who are devoted to the Almighty God, noble, healthy, knowledgeable, competent, creative, independent, and become democratic and responsible citizens. Quality of education refers to a quality education. Quality education is produced by the leadership of a qualified madrasah headmaster, and a qualified headmaster must be professional. A professional madrasah headmaster possesses capabilities of managing and developing madrasas comprehensively and thoroughly. Therefore, he holds a very important and strategic role in actualizing the madrasah's vision, mission and goals.In carrying out his duties, he is full of quality improvement, to produce qualified outputs and outcomes. The professionalism of the madrasah headmaster will show the quality of madrasa performance.

According to E Mulyasa, "A headmaster must be able to carry out duties as an educator, manager, administrator, and supervisor(EMAS)". ${ }^{5}$ Adopting to the needs of the community and the development era, the madrasa head must also be able to act as

\footnotetext{
${ }^{5}$ Mulyasa. MenjadiKepalaSekolah Professional. (bandung: PT. Raja Grafindo: 2006), 98.
}

a leader, innovator, motivator, and entrepreneur in his Madrasa.

The success of a headmaster in leading a madrasa indicates that the madrasa head is a person who determines the focal point and rhythm of a madrasa. As the top leader, he has the authority, power and effective leadership strategies to manage and develop his subordinates professionally.

\section{Literature Review}

\subsection{Previous Research}

The substance of this research focuses on the study of the madrasa headmaster strategy in improving the quality of Islamic Education in Madrasah TsanawiyahAlkhairaatSibalaya. It has been widely presented in seminars, theses, printed books and literature relating to the topics discussed, including:

1. Research conducted by Abdul Latif Tahir entitled "Participatory Leadership of Madrasah Headmaster in Improving the Quality of Education in State Madrasah IbtidaiyahBitung." The result of the research revealed that the leadership performed by the headmaster of State Madrasah IbtidaiyahBitung is indicated as Participatory leadership style. The indication is that the headmaster in determining action plans and tasks implementation plan always involves subordinates to improve the quality of 
learning including in strategic decision making for madrasah development.

2. Research conducted by SittiSarihati entitled "The Role of Madrasah Headmaster's Leadership in Improving Teachers' Work Motivation in Islamic Boarding School of Sultan HasanuddinPattunggalengangKec.

BajengKab. Gowa ". This research revealed that the leadership style performed by the madrasah headmaster varies greatly depending on the situation and maturity of the teachers. Dictatorial/authoritative style is performed in occasions where decisions should be made immediately or when guidance and directions are required by the teachers in completing the tasks they less understand. Performing Participatory/Democratic style because it requires participation or suggestions from the teacher before making a decision. Sometimes laissez faire style, because the headmaster considers the teacher to have high maturity in carrying out their duties, he let them independently do the task he delegated.

3. Research conducted by Usman $M$. Batulipu with the title "The Role of Professional Teachers in Improving the Quality of Education in MTs AlKhairatBunoboguBuol District". The results revealed that the education quality improvement in MTs Al-

KhairatBunoboguBuol District, has not been said to be optimally successful, but teachers have carried out their duties professionally despite the obstacles in conducting the learning process. Teachers participate in training activities, discussion seminars, and are demanded to improve their education to a high level. Therefore, it is expected that they have ambitions to improve their performance better so that gradually the deficiencies can be overcome.

4. The researches above, although there are differences both in terms of discussion and others, are helpful and useful as references in conducting research so that this research can provide better conclusions or answers.

\subsection{Overview of the Madrasah Headmaster} Strategy

A strategy is generally designed by someone before conducting an activity. For instance military forces preparing for war, or a football coach before competing in a match, they must first design a strategy. A madrasah headmaster leader as well should be well-prepared with a variety of strategies.

Strategy comes from the word strategos (Greek) or strategus, means 
general or also means state officer. ${ }^{6}$ Strategy can be interpreted as ways, tactics, tricks, tips. ${ }^{7}$ In terminology, strategy is an outline of direction in acting to achieve the goal.

SyaifulBahriDjamarah stated that strategy is a way or a method, while in general strategy is interpreted as an outline of direction in acting as an effort to achieve the predetermined target. ${ }^{8}$ Strategy is a structuring of potential and resources in order to efficiently obtain the results of a design. Tactic is the optimal use of situations and conditions to reach the target. In military, strategy is used to win a war, tactics are used to win battles. ${ }^{9}$

Nanang Fattah stated that:

Strategy is systematic steps in implementing a comprehensive (macro) and long-term plan in achieving goals. In addition, strategy is conceptual, realistic, and comprehensive thinking about the steps needed to achieve the goals and objectives set. ${ }^{10}$

Based on several opinions raised by the experts above, the researchers conclude

\footnotetext{
${ }^{6}$ AnnisatulMufarokah, Strategi Belajar Mengajar( Yogyakarta: Teras, 2009), 36.

${ }^{7}$ Tim Penyusun, Kamus Bahasa Indonesia, (Jakarta: PusatBahasa, 2008), 152.

${ }^{8}$ Syaiful Bahri Djamaroh, Aswan Zain. Strategi Belajar Mengajar (Jakarta: RinekaCipta, 2002), 5.

${ }^{9}$ NoengMuhajir, Ilmu Pendidikan dan Perubahan Sosial: Teori Pendidikan Pelaku Sosial Kreatif (Yogyakarta: Rake Sarasin, 2000),138-139.

${ }^{10}$ Nanang Fattah, Konsep Manajemen Berbasis Sekolah dan Dewan Sekolah Bandung: Pustaka Bani Quraisy, 2004), 31.
}

that strategy is a way or integrated direction steps for madrasas which provides guidelines to mobilize the resources to achieve goals.

\subsection{The Leadership of Madrasa Headmaster}

The term leadership comes from the word Leader. ${ }^{11} \mathrm{~A}$ leader is someone who has the ability to influence the behavior of others in his working environment with power. Power is the ability to direct and influence subordinates regarding the tasks that must be performed. ${ }^{12}$ Meanwhile, according to Koontz and Donnel, leadership is an art and the process of influencing people so that they will strive willingly and enthusiastically to achieve group goals. ${ }^{13}$

According to Stogdill, leadership is a process of influencing group activities to satisfy and achieve goals. Meanwhile, according to George Terry, leadership is an activity of influencing others to strive willingly for group objectives. ${ }^{14}$

According to Dirawat et al, in his book "PengantarKepemimpinanPendidikan" which states that: Leadership means the skill and readiness possessed by someone to be

\footnotetext{
${ }^{11}$ Mardiyah, Kepemimpinan Kiai dalam Memelihara Budaya Organisasi. (Malang: Aditya Media Publishing. 2012), 37.

${ }^{12}$ Jamal Ma'mur Asmani, Manajemen Pengelolaan dan Kepemimpinan Pendidikan Professional: Panduan Quality Control Bagi Para Pelaku LembagaPendidik, (Cet. I; Yogyakarta: Diva Press, 2009), 92-94.

${ }^{13}$ Ibid., 112

${ }^{14}$ VeithzalRivai, \&SylvianaMurni, Education Managemen Analisis Teori dan Praktik(Jakarta: PT. RajaGrafindoPersada. 2009), 285.
} 
able to influence, encourage, invite, guide, move and if necessary force others to accept then do something that can help achieve a certain purpose or goals. ${ }^{15}$

Thus, the notion of leadership is essentially the ability and readiness possessed by someone to be able to influence, encourage, invite, guide, mobilize, and if necessary, force others to accept that influence and then do something that can help achieve a particular purpose or goal.

The person who holds the position of madrasah headmaster is the leader of education. This may be true, but leadership itself is not a function of position. The madrasah headmaster title does not guarantee that the headmaster is an education leader. Leadership does not mean having full control, but the art of convincing people to work hard towards common goals. $^{16}$

Madrasas headmasters are essentially functional workers who are given the task to lead the administration of a madrasa. Therefore, the competencies emphasized on the duties of the madrasah head are not competencies in the learning process, but competencies expressed by Lipham below:

\footnotetext{
${ }^{15}$ Dirawatdkk, Pengantar Kepemimpinan Pendidikan(Cet. III; Surabaya: Usaha Nasional, 1986), 23.

${ }^{16}$ Rahmat, Kecerdasan Emosional Kepemimpinan Kepala Madrasah (Cet. I; Bandung: Refika Aditama, 2008), 33.
}

The ability to analyze problems, the ability to give various considerations, organizational skills, the ability to make decisions, the ability to lead, high sensitivity, graceful or patient, the ability to communicate in writing, the desire to participate and the ability to discuss actual events, highly motivated and understand background philosophy of education well. ${ }^{17}$

The madrasah headmaster is the driving force, determining the direction of madrasah policy, who will determine how madrasah and educational goals are generally actualized. In connection with Madrasah-Based Management, madrasah headmasters are demanded to constantly improve the effectiveness of performance. Therefore, Madrasah Based Management as a new paradigm of education can provide satisfying results. ${ }^{18}$

The success of education in the madrasah is largely determined by the success of the madrasah headmaster in managing and empowering all resources of madrasah, including the development of teachers and staff. Improvements in productivity and working performance can be actualized through the application of

\footnotetext{
${ }^{17}$ Wahjosumidjo, Kepemimpinan Kepala Madrasah: Tinjauan Teoretik dan Permasalahannya (Cet. VI; Jakarta: Rajawali Pres, 2008), 366.
}

${ }^{18}$ E. Mulyasa, Manajemen Berbasis Madrasah: Konsep, Strategi, dan Implementasi (Cet. XI: Bandung: Remaja Rosda Karya Offset, 2007), 126. 
modern personnel management concepts and techniques.

Educational leadership performance is all the efforts made and the results achieved by the madrasa headmaster in actualizing educational goals effectively and efficiently. Effective madrasah headmasters based on the above criteria are as follows;

Able to empower educators and educational personnel to actualize a good, smooth and productive learning process, able to carry out tasks and work in a timely manner and on target, able to establish a harmonious relationship with the community so that they can actively involve them in actualizing the goals of education in the madrasah, able to apply leadership principles in accordance with the level of maturity of educators and education personnel in the madrasah, working collaboratively with the management team, and succeeding in realizing the goals of the madrasah productively according to the conditions set. ${ }^{19}$

Headmaster as the manager of education and learning activities in the madrasah must know, understand and perform their duties properly, including the activities of exploring and utilizing all madrasah's resources as a whole in achieving educational goals.

Leadership is an important power in management so that the ability of leaders is

${ }^{19}$ Nur Zazin, Gerakan Menata Mutu Pendidikan: Teori dan Aplikasi (Cet. I; Yogyakarta: Ar-Ruzz, 2011), 220. the key to the success of organization. The essence of leadership is the willingness of others to follow the leader's wishes. ${ }^{20} \mathrm{~A}$ leader must be able to develop discipline, especially self-discipline. In this case, the leader facilitates employees in developing patterns of upgrading standards of behavior, and implements the rules as a tool to instill respect for authority, cooperation, the need for organization, and respect other people. ${ }^{21}$

Leadership is the process of directing and influencing members to perform various activities in an organization. The process in this case is how leaders use their influence to clarify goals to their subordinates, motivate them to achieve goals and facilitate them to create a good work atmosphere so that staff can be productive in working.

M. Manullang stated that leadership includes five types of activities, they are:

Taking decisions, building effective communication, inspiring and motivating subordinates, selecting people to be involved in the group, and improving the knowledge and attitudes of subordinates to achieve the goals set. ${ }^{22}$

${ }^{20}$ Baharuddin dan Umiarso, Kepemimpinan Islam: Antara Teori dan Praktik (Cet. I; Yogyakarta: Ar-Ruzz Media, 2012), 33.

${ }^{21}$ E. Mulyasa, Manajemen Berbasis Madrasah: Konsep, Strategi, dan Implementasi (Cet. XI; Bandung: Remaja Rosdakarya, 2007), 118.

${ }^{22}$ Imran Fauzi, Manajemen Pendidikan Ala Rasulullah (Cet. I; Yogyakarta: Ar-Ruzz Media, 2012), 215. 
Educational leadership is one of the personal factors in the form of various competencies of a leader that greatly influences the leadership process. In this case, the conception of educational leadership generally focuses on personality of the leaders that is qualities or abilities they possess. ${ }^{23}$

Madrasah headmasters as educational leaders on a daily basis have the main task of influencing, encouraging, inviting teachers and other staff to have willingness to do something that can support the achievement of madrasas as an institution. ${ }^{24}$ The reliability of the teaching staff, perseverance of counseling staff, and the attention of parents, and the surrounding community, in the end, will strengthen madrasah-based education management. $^{25}$

The word "lead" has a broad meaning, that is: the ability to move all the resources in a madrasah and utilize them optimally to achieve the goals set. ${ }^{26}$ One theory views leadership as a person with qualities of a leader, including four criteria,

\footnotetext{
${ }^{23}$ Baharuddin, Kepemimpinan, 72.

${ }^{24}$ Ibrahim Bafadal, Peningkatan Profesional Guru Madrasah Dasar: dalam Kerangka Manajemen Peningkatan Mutu Berbasis Madrasah (Cet. IV; Jakarta: Bumi Aksara, 2008), 89.

${ }^{25}$ Abd. Rahman Halim, Madrasah Antara Kebijakan dan Partisipasi Masyarakat (Cet. I; Makassar: Alauddin University Press, 2011), 199.

${ }^{26}$ Wahjosumidjo, Kepemimpinan Tinjauan Teoritik dan Permasalahannya (Cet. III; Jakarta: RajaGrafindo Persada, 2002), 83.
}

identification with the needs of others, the ability to adjust to group norms, willingness to provide assistance, controlling emotions, high intelligence: social, verbal and academic, interested in leading and enthusiastic. $^{27}$

The key to the success of a madrasa essentially lies in the efficiency and effectiveness of the appearance of the headmaster. The success of the madrasah is the success of the headmaster and the success of the headmaster is the success of the madrasah. ${ }^{28}$

Headmaster leadership performance in relation to madrasah-based management is all the efforts made and results achieved by the headmaster in implementing madrasahbased management in the madrasah to achieve educational goals effectively and efficiently.

Headmaster leadership performance in relation to madrasah-based management is all the efforts made and results achieved by the headmaster in implementing madrasahbased management in the madrasah to achieve educational goals effectively and efficiently. ${ }^{29}$

\footnotetext{
${ }^{27}$ Hamka Ilyas, Konsep dan Teori Pengembangan Kurikulum (Cet. I; Makassar: Alauddin University Press, 2011), 217.

${ }^{28}$ Wahjosumidjo, Kepemimpinan, 349.

${ }^{29}$ M. Arifin, Kapita Selekta Pendidikan Islam: Islam dan Umum (Cet. III; Jakarta: BumiAksara, 1995), 156.
} 
Madrasah headmaster leadership is related to various tasks and functions that must be carried out in actualizing an effective, productive, independent, and accountable madrasah. From the various duties and functions the headmaster must carry out in developing the madrasa effectively, efficiently, productively and accountably, there are at least ten keys to leadership include: full vision, responsibility, providing best services, developing people's skill, fostering a sense of unity, focusing on students, management that prioritizes practice, adjusting leadership style, and utilizing the power of expertise. ${ }^{30}$

The success of madrasah headmasters is often characterized by shared leadership. An effective leader is required to be capable of delegating tasks to all staffs. The delegation involves determining the correct processes, structures, people, information, decisions and awards. To this point, leadership in madrasas tends to implement centralized leadership in which the education unit leaders are mostly waiting for implementation instructions, technical instructions and orders.

Madrasah leadership is an effort to utilize all madrasah resources to achieve the objectives set. The process of influencing will be achieved when madrasah personnel collaborate in synergy as a solid system to

${ }^{30}$ Mulyasa, Manajemen, 22-23. strengthen the madrasa's internal environmental conditions, so that it can live and synergize with other madrasas, the industrial world or others. The headmaster has a role to analyze precisely the various environmental conditions, both internal and external environment of the madrasah, thus the right strategy to bring the madrasa to the expected changes can be produced. ${ }^{31}$

As the word of Allah in Q.S. alBaqarah (2): 30;

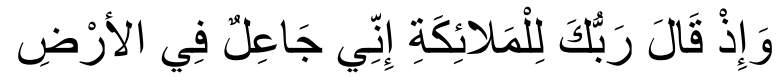

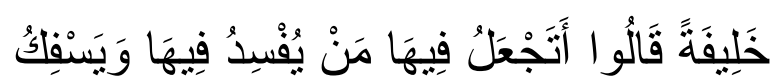

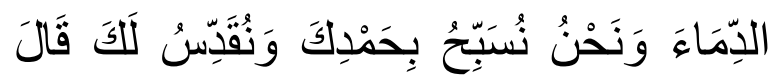

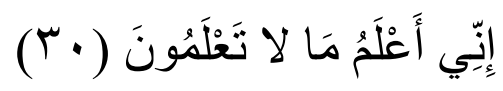

Translation:

And [mention, O Muhammad], when your Lord said to the angels, "Indeed, I will make upon the earth a successive authority." They said, "Will You place upon it one who causes corruption therein and sheds blood, while we declare Your praise and sanctify You?" Allah said, "Indeed, I know that which you do not know." 32

The above verse explains that the presence of a leader will improve the quality of the institution he leads and there must be cooperation among his subordinates. The

\footnotetext{
${ }^{31}$ Minnah El Widdah, dkk., Kepemimpinan Berbasis Nilai dan Pengembangan Mutu Madrasah (Cet. I; Bandung: Alfabeta, 2012), 69.

${ }^{32}$ Departemen Agama RI, Al-Qur'andan Terjemahnya (Bandung: Syamil Cipta Media, 2005), 6.
} 
verse also recommends that a leader must be knowledgeable and have high integrity.
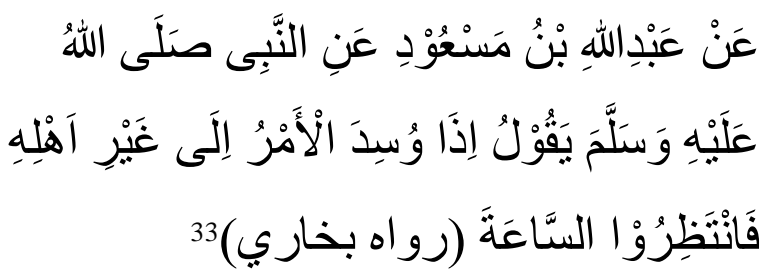

Meaning:

If a matter is left to the non-expert, wait for destruction.

Madrasah headmaster leadership is an ability and readiness of the headmaster to influence, guide, direct, and move the staffs to work effectively in achieving educational and teaching goals that have been set, or it can also be defined as assistance given by madrasah headmaster in determining the achievement of educational goals.

\section{Methodology}

This research uses qualitative approach with

Madrasah

TsanawiyahAlkhairaatSibalayaSigi Regency as the object to be investigated. The researchers chose this location based on some considerations, it is located in Sibalaya Village, Tanambulava District, Sigi Regency based on the Decree of the Head Office of the Ministry of Religion of Central Sulawesi,

\footnotetext{
${ }^{33} \mathrm{Al}-$ Imam Abi Abdillah Ibnu Isma‘il Ibnu Ibrahim Ibnu al-Mughirah Ibnu Bardazaha alBukhariy al-Ja'fiy, Shahih Bukhariy, juz I (Dar alFikr, 1981), 21.
}

the status is recognized until now with the vision of promoting the Madrasah Tsanawiyah Alkhairaat Sibalaya as Innovative, prestigious, and has a character. Data were collected using observation techniques, in-depth interviews and studies from shared written documents. The data analysis is done using reduction and verification techniques with various data sources. The reduced data is then analyzed by claiming to the theoretical concepts used in this research.

\section{Result and Discussion}

4.1 Madrasah Headmaster Strategies in Improving the Quality of Islamic Education

Educational quality improvement strategy in Madrasah TsanawiyahAlkhairaatSibalaya is in line with the situation and needs of the community. The development of the madrasah is carried out as a form of community service. The strategy to improve its educational quality is implemented by the headmaster resulting on encouragement to the community to educate their children in the madrasah.

$$
\text { Madrasah educational quality }
$$
improvement is a plan prepared based on the profile of the madrasah. Thus, the profile becomes considerations to improve the quality and quantity of education. The 
educational quality improvement refers to the implementation of madrasah-based management. The development plans are prepared by involving all madrasah elements, including headmaster, teachers, committees, parents of students, communities, community leaders, and religious leaders. By involving various elements, madrasah can meet the needs of the community.

\section{Madrasah}

TsanawiyahAlkhairaatSibalaya as one of the institutions of Islamic education that plays a role in developing Islamic education in the community teaches both general and Islamic education. This madrasah is under the guidance of the Ministry of Religion and the Ministry of Education which grows and develops as a part of the culture of the Sibalaya people. This madrasah is also able to survive with its own character, which is able to foster students to be religious and noble. This character distinguishes between public schools and Islamic schools. In addition to fostering the spirit of religion and noble character, this madrasa also plays a role in the intellectual life of the nation and the achievement of national education goals.

Improving the quality of madrasah education performed by the headmaster with all its potential is one of the efforts to improve the quality of madrasah so that it can be accepted by the society and graduates of madrasas are able to adapt, socialize and fight for society, nation and state. ${ }^{34}$

The development of science and knowledge gives a positive impact on the world of education including the development of madrasah. The headmaster of Madrasah

TsanawiyahAlkhairaatSibalayaadjust the education in the madrasah to fit with the development of society. The purpose of madrasa development holds an important role in the formation of learners' intellectual, emotional, spiritual, becoming a medium of the students' talents and potential development and ensuring students to get equal and appropriate learning opportunities.

\section{Madrasah}

TsanawiyahAlkhairaatSibalaya seeks to compete with other schools. Therefore, a lot of development and educational quality improvement are especially in facilities and infrastructure and the quality of educators and education staffs. If all is fulfilled then the

Madrasah

TsanawiyahAlkhairaatSibalaya will be able to compete with other schools.

The strategy of the madrasah head in improving the quality of education in the Madrasah TsanawiyahAlkhairaatSibalaya begins with an analysis of the internal and

\footnotetext{
${ }^{34}$ Ade Irma, WakilKepala Madrasah Bidang Kurikulum, “Wawancara”, Ruang Wakamad, 17 Juli 2017.
} 
external environment in this case identifying threats and opportunities then proceed with making a vision, mission and goals. After the vision, mission and objectives are formed then choose the strategy that will be used to improve the quality of education. After choosing a strategy then it is implemented through programs and policies and then to be evaluated.

\subsection{Madrasah Headmaster Strategies in} Identifying Threats and Opportunities

The strategy undertaken by the headmaster in improving the quality of education in Madrasah TsanawiyahAlkhairaatSibalaya begins with an analysis of the internal and external environment which includes strengths and weaknesses, as well as the threats and opportunities. The following is an explanation from the headmaster related to the strengths and weaknesses of the Madrasah:

As we all know that in a madrasah, Islamic education is the first priority, as the main strength that is usually called madrasah plus. More than that, we have qualified educators and education staffs with the range of education degree from S1 and some even have Master degree. I can say they are young generation with excellent performance. ${ }^{35}$

${ }^{35}$ Mustapa, Kepala Madrasah Tsanawiyah Alkhairaat Sibalaya, "Wawancara”, Ruang Kepala Madrasah, 12 Juli 2017.
Furthermore, Mr. Mustapa added:

The threats faced today are the development era, especially now the era of globalization in which everything can be accessed easily, and worsened by the condition of people who are less aware of the importance of religion. However, there are also opportunities that a number of people who already aware of and fully support our madrasah and the public interest in continuing to send their children to Madrasah. ${ }^{36}$

Based on several weaknesses and strengths found in the Madrasah TsanawiyahAlkhairaatSibalaya, the headmaster realized that there is no perfect educational institution. Every educational institution must have weaknesses. However, the headmaster has the determination not to make weaknesses as threats, but instead transforming weaknesses into power to achieve quality improvement in education. Weakness is a warning to the headmaster to be more concerned with the existing problems. Considering the threats and opportunities, the headmaster takes action to transform some threats into solution to become a profitable opportunity for madrasah development.

${ }^{36}$ Mustapa, Kepala Madrasah Tsanawiyah Alkhairaat Sibalaya, "Wawancara”, Ruang Kepala Madrasah, 12 Juli 2017. 


\subsection{Strategy Formulation of Madrasah Headmaster}

To give an illustration of the madrasa in the future specifically the quality development of education, it is necessary to look at the strategic efforts especially the quality improvements of educators and education personnel, financing, and quality education facilities fulfillment. Madrasah prepares students to have skills to compete in science and technology, but still hold Islamic values. The quality of education in Madrasah TsanawiyahAlkhairaatSibalaya is influenced by the leadership pattern of the headmaster. One of supporting factors in the education quality of this madrasa is influenced by the leadership pattern of the headmaster. His effort to improve the quality are very urgent and unavoidable demands. To formulate the vision and mission of the headmaster prepare students to be able to compete in science and technology.

The headmaster of Madrasah TsanawiyahAlkhairaatSibalaya is able to create a conducive situation in the madrasah including having the ability to interact and being able to appreciate and understand the attitudes, behaviors, needs, hopes and demands of his subordinates, also guiding his subordinates with a friendly and wise attitude. In the interview, the headmaster said:
All teachers and staffs implement the rules that have been determined based on agreement. The implementation of all regulations will create conducive and productive work atmosphere. We often hold refreshing events, such as semester breaks, sports and art events, field trips and study tours. We also organize the room as comfortable as possible so that the teachers, staffs and students do not get bored and feel like home. $^{37}$

One of the Madrasah TsanawiyahAlkhairaatSibalaya teachers revealed that:

The headmaster, teachers, and staffs run according to their respective duties. This means that there is no social jealousy with the task at hand. Mutual understanding, mutual assistance and good cooperation can avoid misunderstanding. All must understand, that people have strengths and weaknesses. For teachers, teaching must be on time. Punctuality will create a harmonious situation with students. ${ }^{38}$

The interview above show that the Headmaster as a leader always builds harmony in the organization for example being able to place personnel appropriately and to influence his subordinates in human relations which are covered by authority situations. The creation of a conducive situation in madrasah will build kinship and

\footnotetext{
${ }^{37}$ Mustapa, Kepala Madrasah Tsanawiyah Alkhairaat Sibalaya, "Wawancara”, RuangKepala Madrasah, 12 Juli 2017.

${ }^{38}$ Wirna, Guru Mata Pelajaran Qur'an Hadits, “Wawancara”, Ruang Guru, 17 Juli 2017.
} 
avoid misunderstanding and unfair competition.

The Headmaster of Madrasah TsanawiyahAlkhairaatSibalaya always creates a harmonious relationship with his subordinates in the scope of educational institutions so that comfortable, calm, and conducive atmosphere as well as loyalty and integrity will arise. More than that, there is a good emotional relationship with subordinates. Based on the results of interviews with SKI teachers, said:

In the free time, teachers and the headmaster discuss about the progress of the madrasah. Problems are discussed openly to be solved together. Every teacher is not justified to be selfish, respecting senior teachers, and guiding junior teachers. ${ }^{39}$

The headmaster as a leader in an educational institution has a close relationship with staffs and teachers in order to achieve educational goals that have been formulated together. On the other hand, in carrying out leadership, he needs to know and understand various positions, circumstances, and what is desired, both by teachers and staffs, so that the good cooperation can produce harmony in developing madrasah. All of these things need to be taken into consideration for

${ }^{39}$ Hasna, Guru Mata Pelajaran Sejarah Kebudayaan Islam, “Wawancara”, Ruang Guru, 18 Juli 2017. madrasah headmaster in mobilizing all members he leads.

\subsection{Implementation of Madrasah Headmaster Strategy}

Headmaster strategy is an important factor in determining the success of the quality of education improvement in madrasas. The strategy of the headmaster in the

Madrasah

TsanawiyahAlkhairaatSibalaya is carried out in various ways as follows:

In the process of decision making about strategies to improve the quality of education, it is not taken and decided one-sidedly by the headmaster, but involves all elements of the madrasah including the deputy head of the madrasa, chair of the committee, and all teachers. ${ }^{40}$

The data obtained from the interview explained that all elements related to the madrasah play their roles in improving the quality of education. The headmaster of the Madrasah TsanawiyahAlkhairaatSibalaya not only focuses on improving the quality, but also supervises and guides teachers and school staff or administration in terms of discipline, competence and performance. As stated by one of the teachers at Madrasah TsanawiyahAlkhairaatSibalaya, that:

${ }^{40}$ Ade Irma, WakilKepala Madrasah Bidang Kurikulum, “Wawancara”, Ruang Wakamad, 17 Juli 2017. 
The Head of Madrasa is very disciplined and strict in applying disciplinary rules to all teachers, especially teachers with the status of Civil Servants (PNS). For example the obligation to be present at madrasah before class time, no later than $7 \mathrm{am}^{41}$

The same thing was expressed by the deputy headmaster curriculum of the madrasah saying:

To apply discipline to teachers and staff at Madrasah TsanawiyahAlkhairaatSibalaya, the headmaster gives penalty in the form of verbal reprimand and if it still goes on, a written warning will be given. ${ }^{42}$

The interview result above shows that the headmaster is very discipline and applies the discipline to the whole personnel of the madrasah making them as a good role model for the students. Discipline is one aspect that needs to be applied in the madrasa environment so that the quality of education can be improved. In addition, the headmaster is also required to innovate for the progress of educational institutions and hold the commitment to develop madrasah. As stated by the headmaster, that:

There are several innovations that we have run at the Madrasah TsanawiyahAlkhairaatSibalaya

${ }^{41}$ Hasna, Guru Mata Pelajaran Sejarah Kebudayaan Islam, “Wawancara”, Ruang Guru, 18 Juli 2017.

${ }^{42}$ Ade Irma, Wakil Kepala Madrasah Bidang Kurikulum, “Wawancara”, RuangWakamad, 17 Juli 2017. including performing the Dhuha prayer every Friday and giving Islamic speech training to students every Monday-Thursday after the midday prayer. Of course we do this as an effort to strengthen the quality of the students' faith and in the community they are used to doing religious speech. ${ }^{43}$

Based on the results of the interview above, the headmaster has done innovations which bring positive impacts on madrasah development. In performing his role, he is required to discover new things related to the development of the education, and respond the wishes of the community so that changes bring results in line with community expectations.

In addition, the headmaster also did a number of things related to teachers' competency improvements which have a direct impact on improving the quality of education, as conveyed by Fiqhi teacher.

A school teacher said that:

The headmaster always involves the teacher in seminars, trainings, and certification and encourages teachers to get involved in MGMP (Subject Based Teachers Consultation Forum), and to continue their undergraduate education for some teachers who are still diplomas and those who have already graduated to continue to the magister (strata two) program.sarjanajugadiberikankesemp

${ }^{43}$ Mustapa, Kepala Madrasah Tsanawiyah Alkhairaat Sibalaya, "Wawancara”, Ruang Kepala Madrasah, 12 Juli 2017. 
atanuntuklanjutpadajenjang S2 (strata dua). ${ }^{44}$

The headmaster is responsible for the quality of development and empowerment of Human Resources in the madrasah so that they are able to carry out their duties effectively. In other words, as the manager of education, he has the task of improving the competence of teachers and staff, transforming them into professional teachers and employees to achieve quality education. With the empowerment of teachers, their skills will increase and it will automatically impact on the improvement of the students' ability as well, ultimately also improving the quality of education in Madrasah TsanawiyahAlkhairaatSibalaya.

\subsection{Evaluation}

Evaluation is a planned activity to find out the state of an object using instruments and comparing the results with standards to obtain conclusions. Information about the extent to which the success of an educator provides material and to which the students absorb materials presented, can be obtained through evaluation. Regarding the evaluation in the Madrasah Tsanawiyah Alkhairaat Sibalaya, Mr Mustapa as the headmaster stated that:

\footnotetext{
${ }^{44}$ Misbah, Guru Mata Pelajaran Fiqhi, “Wawancara”, Ruang Guru, 17 Juli 2017.
}

The evaluation of learning activities in the Madrasah Tsanawiyah Alkhairaat Sibalaya is carried out by the headmaster and subject supervisors. The objects of Evaluation include the success of teachers in providing material and the students' comprehension on the materials presented. ${ }^{45}$

In line with the above statement, Mrs. Ade Irma, as the deputy head curriculum of the madrasa also stated that:

The technical targets in evaluating
learning outcomes are the teaching
methods, the use of instructional
media, the learning management, the
idealism of the teacher towards
learning outcomes and student
productivity, students' work, the use of
learning resources, ways of
assessment, manners in treating
students, providing training and
assignments, and learning
interactions. ${ }^{46}$ and Based on the statement above, the evaluation in the learning process is carried out by the headmaster and supervisors. This shows that the evaluation activities in the learning process of the Madrasah TsanawiyahAlkhairaatSibalaya have been going well, touching on several key targets in the learning process and involving relevant and professional parties so that it is expected to improve the quality of education in the Madrasah.

\footnotetext{
${ }^{45}$ Mustapa, Kepala Madrasah Tsanawiyah Alkhairaat Sibalaya, "Wawancara”, Ruang Kepala Madrasah, 12 Juli 2017.

${ }^{46}$ Ade Irma, Wakil Kepala Madrasah BidangKurikulum, "Wawancara”, RuangWakamad, 17 Juli 2017.
} 
In addition, the vision, mission and objectives of the madrasah need to be reviewed and evaluated periodically in order to identify the level of achievements and the problems interfering the realization of the three main pillars of the madrasah. Evaluation is also important so that the pillars can be in line with the needs and challenges faced by the madrasah community and the citizens. According to the headmaster of the Madrasah TsanawiyahAlkhairaatSibalaya that:

Madrasah agrees to evaluate the vision, mission and goals. The time is adjusted to the needs. At least once a year we review the formulation and substance of the vision, mission and objectives, which parts have been achieved and which parts have not. Adjustments are made to certain parts that are considered no longer in line with the needs. In addition, the evaluation targets are also the hindering factors and problems in the implementation of the three pillars. ${ }^{47}$

The evaluation steps taken are considered in line with efforts to improve the quality of education. Because the vision, mission and goals of schools are the main pillars of the development and improvement of the quality of education. Therefore the level of achievement of the vision, mission and objectives of the madrasa is an indicator of the progress. Reversely, the inability of

\footnotetext{
${ }^{47}$ Mustapa, Kepala $\quad$ Madrasah TsanawiyahAlkhairaatSibalaya, "Wawancara", RuangKepala Madrasah, 12 Juli 2017.
}

madrasa community to actualize these three pillars is an indicator of the regression. The pillars must also be in line with the needs of the students as well as the development and demands of the community at the local, regional, national and global level.

\section{Conclusion}

This research concludes that the strategy of the headmaster in improving the quality of Islamic Education in the Madrasah TsanawiyahAlkhairaatSibalaya begins with an analysis of internal and external environment in this case identifying threats and opportunities then proceeded with formulating vision, mission and goals. After the three pillars are set, the strategy to improve the quality of education is planned, implementing it through programs and policies and doing evaluation.

The success of the quality improvement program of Islamic Education in madrasah is generally inseparable from several supporting and inhibiting factors. To support the headmaster of Madrasah Tsanawiyah Alkhairaat Sibalaya in quality improvement, good cooperation with subordinates is essential as well as conducive situation and condition. Meanwhile, the inhibiting factors are the lack of discipline among teachers and poor 
and negative response of the communities to send their children to madrasa.

The solution to overcoming these obstacles is that the madrasah headmaster always upholds the rules of the teacher. Breaking the rules must be given sanctions according to the type of violation. If it is severe, he will be expelled from the madrasa. In upholding teacher discipline, the main thing done by the headmaster is to set an example. In addition, to overcome the lack of response and negative treatment from the community, the madrasa stakeholder collaborates with religious leaders, the supporting community and madrasa committees to socialize the madrasa so that the community sent their children to madrasa and all the components of society participate in it's development.

\section{References}

Adholina, Ifa, Implementasi Manajemen Pendidikan dalam Meningkatkan Mutu Pendiidkan di SLTP 03 Batu, Skripsi UIN Malang, 2005.

Ainurrafiq Dawam dan Ahmad Ta'rifin, Manajemen Madrasah Berbasis Pesantren Cet. I; Listafariska, 2004.

Al-Imam Abi Abdillah Ibnu Isma'il Ibnu Ibrahim Ibnu al-Mughirah Ibnu Bardazaha al-Bukhariy al-Ja'fiy, Shahih Bukhariy, juz I, Dar al-Fikr, 1981.

Arcaro, Jeromi S., Pendidikan Berbasis Mutu, Prinsip- prinsip Perumusandan Tata Langkah Penerapan, Yogyakarta: Pustaka Pelajar, 2006.

Ari, Donalet. al. Introduction to Research, diterjemahkan oleh Arief Rahman,
Pengenatar Penelitiandan Pendidikan. Surabaya: Usaha Nasional, t.th.

Arifin, M, Kapita Selekta Pendidikan Islam: Islam dan Umum, Cet. III; Jakarta: BumiAksara, 1995.

Arikunto, Suharsimi, ManajemenPenelitian,

Cet. VII; Rineka Cipta, 2005.

Suatu Pendekatan Praktek, Jakarta: Rineka Cipta, 1993.

Asmani, Jamal Ma'mur, Manajemen Pengelolaandan Kepemimpinan Pendidikan

Professional: Panduan Quality Control Bagi Para Pelaku Lembaga Pendidik, Cet ke-1; Yogyakarta:: Diva Press, 2009.

Bafadal, Ibrahim, Peningkatan Profesional Guru Madrasah Dasar: dalam Kerangka Manajemen Peningkatan Mutu Berbasis Madrasah, Cet. IV; Jakarta: Bumi Aksara, 2008.

$\begin{array}{lcr} & \text { Seri } & \text { Manajemen } \\ \text { Peningkatan } & \text { Mutu } & \text { Pendidikan } \\ \text { Berbasis Madrasah: dari } & \text { Sentralisasi } \\ \text { Menuju Desentralisasi, } & \text { Cet. III; } \\ \text { Jakarta: Bumi Aksara, 2009. }\end{array}$

Baharuddin dan Umiarso, Kepemimpinan Islam: Antara Teori dan Praktik, Cet. I; Yogyakarta: Ar-Ruzz Media, 2012.

Bungin, Burhan, Analisis Data Penelitian,Cet.II; Jakarta: Raja Grafindo, 2003.

Danim, Sudarwan, Visi Baru Manajemen Madrasah, Cet. III; Jakarta: Bumi Aksara, 2008.

Departemen Agama RI, Al-Qur'andan Terjemahnya, Bandung: Syamil Cipta Media, 2005.

Dirawatdkk, PengantarKepemimpinanPendidikan, Cet III, Surabaya: Usaha Nasional 1986.

Dit. Dikdasmen, Depdiknas, Manajemen Peningkatan Mutu Berbasis Madrasah, Buku IKonsepdan Pelaksana, Jakarta, 2001. 
Djamaroh, SyaifulBahri, Aswan Zain. Strategi Belajar Mengajar, Jakarta: Rinekacipta 2002.

Erry, H. Makawimbang, Supervisi dan Peningkatan Mutu Pendidikan (Cet. I; Bandung: Alfabeta, 2011.

Fattah, Nanang. Konsep Manajemen Berbasis Sekolah dan Dewan Sekolah. Bandung: Pustaka BaniQuraisy, 2004. Sistem Penjaminan Mutu Pendidikan: dalam Penetapan MBS, Cet. I; Bandung: Remaja Rosdakarya Offset, 2012.

Hadi, Sutrisno.Metodologi Research, Jilid I. Cet. XXIX; Yogyakarta: Andi Yogyakarta, 1997.

Halim, Rahman, Abd.Madrasah Antara Kebijakan dan Partisipasi Masyarakat, Cet. I; Makassar: Alauddin University Press, 2011.

Hasbullah, Kapita Selekta Pendidikan Islam, Cet. I; Jakarta: RajaGrafindo Persada, 1996.

Idris, ZaharadanLisma Jamal, Pengantar Pendidikan, Jakarta: PT. Gramedia Widiasarana Indonesia, 2002.

Ilyas, Hamka, Konsep dan Teori Pengembangan Kurikulum, Cet. I; Makassar: Alauddin University Press, 2011.

Imran, Manajemen Pendidikan Ala Rasulullah Cet. I; Yogyakarta: ArRuzz Media, 2012.

Maksum. Madrasah: Sejarah dan Perkembangannya, Cet. I; Jakarta: Logos Wacana Ilmu, 1999.

Mardiyah, Kepemimpinan Kiaidalam Memelihara budaya organisasi. Malang: Aditya media publishing. 2012.

Marno dan Triyo Supriyanto, Manajemen Kepemimpinan Pendidikan Islam, Bandung: Refika Aditama, 2008.

Milles, Matthew B. et.al, Qualitative Data Analisys, diterjemahkan oleh Tjetjep Rohendi Rohidi dengan judul Analisis data Kualitatif, buku sumber tentang Metode-MetodeBaru. Cet. I; Jakarta: UI-Pres, 1992.
Moleong, Lexy J., Metode Penelitian Kualitatif, Bandung: Remaja Rosda Karya, 2000.

Mufarokah, Annisatul.

StrategiBelajarMengajarYogyakarta:

Teras, 2009.

Muhajir, Noeng. Ilmu Pendidikan dan Perubahan Sosial: Teori Pendidikan Pelaku Sosial Kreatif, Yogyakarta: Rake Sarasin, 2000.

Muliawan, Jasa Ungguh. Pendidikan Integratif: Upaya Mengintegrasikan Kembali Dikotomi Ilmu dan Pendidikan Islam, Cet. I; Yogyakarta: Pustaka Pelajar, 2005.

Mulyana, Dedi. Metode Penelitian Kualitatif. Bandung: Remaja Rosdakarya, 2008.

Mulyasa. Menjadi Kepala Sekolah Profesional Dalam Konteks Mensukseskan MBS danKBK, Bandung: PT. Remaja RosdaKarya, 2003.

, Menjadi Kepala Sekolah Professional. bandung: PT. Raja Grafindo: 2006.

Konsep, Strategi, dan Implementasi, Cet. XIII; Bandung: Remaja Rosdakarya, 2002.

- Manajemen Berbasis Madrasah: Konsep, Strategi, dan Implementasi, Cet. XI: Bandung: Remaja Rosda Karya Offset, 2007.

Mulyoto, dkk. Kepemimpinan Kepala Madrasah Dalam Meningkatkan Mutu Madrasah Studi Kasus Tentang Manajemen Kepala Madrasah Tsanawiyah Negeri Bendosari Sukoharjo, Jurnal Teknologi Pendidikan, Vol.1, No. 2, 2013.

Nasution. Metodologi Research (Penelitian Ilmiah). Jakarta: Bumi Aksara, 2003.

Qomar, Mujamil. ManajemenPendidikan Islam, Strategibaru Pengelolaan Lembaga Pendidikan Islam. Malang: Erlangga, 2007. 
Rahmat. Kecerdasan Emosional Kepemimpinan Kepala Madrasah. Cet. I; Bandung: Refika Aditama, 2008.

Rivai, Vaitzal. MemimpinDalam Abad ke-21, Jakarta: PT. Raja GrafindoPersada, 2004. \&SylvianaMurni, Education Managemen. Analisis Teori dan Praktik, Jakarta: PT. Raja Grafindo Persada, 2009.

Rohiat, Manajemen Madrasah Teori dan Praktik, Cet. II; Bandung: Refika Aditama, 2009.

Rohiat. Kecerdasan Kepemimpinan Kepala Sekolah. Bandung: PT Refika Aditama, 2008. . Manajemen Sekolah, Bandung: Refika Aditama. 2010.

S. Margono, Metode Penelitian Pendidikan, Cet. II; Jakarta: RinekaCipta, 2000.

Saude, et.al. MetodologiPenelitian. Cet.I; Palu: YayasanMasyarakat Indonesia Baru, 2008.

SittiSarihati, Peranan Kepemimpinan Kepala Madrasah dalam Meningkatkan Motivasi Kerja Guru di MTs Pesantren Sultan Hasanuddin PattunggalengKec. Bajeng Kab. Gowa".Tesis tidak diterbitkan, Makassar: Program Pascasarjana UIN Alauddin Makassar, 2011.

Soetopo, Hendiyat dan WastSoemanto, Kepemimpinan dan Supervisi Pendidikan Cet. II; Jakarta: Bina Aksara, 1988.

Stephen P. Mary dan Robbins Coulter, Manajemen, Jakarta: PT. Prenhallindo, 1999.

Sugiono. Metode Penelitian Pendidikan; Pendekatan Kualitatif, dan $R$ dan $D$. Bandung: Alfabeta, 2008.

Sukmadinata, Syaodi, Nana, dkk., Pengendalian Mutu Pendidikan Madrasah Menengah: Konsep, Prinsip, dan Instrumen, Cet. II; Bandung: Refika Aditama, 2008.

Surakhmad, Winarno. DasardanTeknik Research, Pengentar Metodologi Ilmiah. Bandung: Torsito, 1978.
Suryadi, Manajemen Mutu Berbasis Sekolah Konsep dan Implikasi, Jakarta: PT. Sarana Panca Karya Nusa, 2009.

Tahir, Abdul Latif. "Kepemimpinan Partisipatif Kepala Madrasah dalam Peningkatan Mutu Pendidikan di Madrasah Ibtidaiyah Negeri Bitung". Tesis tidak diterbitkan Makassar: Program Pascasarjana UIN Alauddin Makassar, 2009.

Tanzeh, Ahmad. Metode Penelitian Praktis. Jakarta: BinaIlmu, 2004.

Tim Penyusun, Kamus Bahasa Indonesia, Jakarta: PusatBahasa, 2008.

Triton PB, Manajemen Strategis Terapan Perusahaan dan Bisnis, Cet. I; Yogyakarta: Tugu Publisher, 2007.

Umar, Husein. Metode Penelitian untuk Skripsi dan Tasir Bisnis. Cet. IV; Jakarta: PT. Raja Grafindo, 2000.

Umiarso dan Imam Gozali, Manajemen Mutu Madrasah di Era Otonomi Pendidikan: Menjual Mutu Pendidikan dengan Pendekatan Quality Control Bagi Pelaku Lembaga Pendidikan, Cet. I; Yogyakarta: IRCiSoD, 2010.

Usman M. Batalipu, "PerananGuru Profesional dalam Meningkatkan Mutu Pendidikan di MTs Al-Khairat Bunobogu Kabupaten Buol". Tesis tidak diterbitkan, Makassar: Program Pascasarjana UIN AlauddinMakassar, 2012.

W.J.S Poerwadarminta, Kamus Umun Bahasa Indonesia, Jakarta: BalaiPustaka, 1976. Wahjosumidjo, Kepemimpinan Kepala Madrasah: Tinjauan Teoretik dan Permasalahannya, Cet. VI; Jakarta: Rajawali Pres, 2008.

Kepemimpinan Tinjauan

Teoritik dan Permasalahannya, Cet. III; Jakarta: RajaGrafindo Persada, 2002.

Wahyu, Pedoman Penelitian Pendidikan, Bandung: Tarsito, 1996.

Widdah, Minnah El, dkk., Kepemimpinan Berbasis Nilai dan Pengembangan 
Mutu Madrasah, Cet. I; Bandung:

Alfabeta, 2012.

Zazin, Nur, Gerakan Menata Mutu Pendidikan: Teori dan Aplikasi, Cet. I; Yogyakarta: Ar-Ruzz, 2011. 